\title{
Barthes: "isto foi", isto é. Potências narrativas do visual e da imagem
}

Ver, imaginar com e a partir de Roland Barthes: com essa dupla missão em mente, dobrada, desdobrada e atualizada, editores e colaboradores da vigésima-primeira dentição de outra travessia buscam pensar e homenagear o escritor e ensaísta francês (1915-2015), agora centenário e desde sempre vivíssimo, como se pode observar aqui, em três partes ou "cenas", as duas primeiras especialmente cedidas por pesquisadores latino-americanos à revista: o dossiê "Políticas de la mirada. Intersecciones entre literatura y fotografía”, organizado por Mario Cámara e Alejandra Josiowicz, e o ensaio "Vida e obra. Roland Barthes e a escrita do diário", de Alberto Giordano; na terceira parte, os sete textos selecionados a partir da chamada barthesiana de outra travessia, em que se propôs figurar e reconfigurar o problema da imagem nos termos que seguem.

Afirmar que imagens estiveram sempre diante dos nossos olhos é dizer o óbvio, se não o obtuso. Desde as décadas finais do século XIX, de todo modo, a pretensa continuidade proporcionada pela vista, que entre outras coisas possibilitava abarcar paisagens, sofre um abalo, ou melhor, recebe um complemento valioso proporcionado pela técnica, cujo ápice são os atuais $I$ -phones, I-pads e outros gadgets de mesma ordem. Aparelhos como tais interrompem, de modo quiçá inusitado, a continuidade ou o contato direto entre a visão e o visto. A possibilidade de extrair detalhes, fragmentos, dos panoramas que a todos cercam, abarcando-nos, antes prerrogativa sobretudo de pintores e gravuristas, de encetar recortes, a serem por sua vez selecionados e compartilhados, faz com que os lugares quaisquer em que demoramos sejam experimentados como cenas, ao menos potencialmente como cenografias.

Esse hoje banal ato de registrar imagens, disseminado em escala imensurável, resulta igualmente de um anseio de fixar um ponto de vista, um concernimento cuja pretensão maior talvez seja montar, pela disseminação e a repetição, uma visão singular, 
uma sensibilidade qualquer, porém situada no e a partir daquele próprio ato. $\mathrm{O}$ olhar sobre algo, nesse sentido, revela não só o que se vê, o visto através do aparelho, mas pretende dar mostras daquele que vê, via aparelho, procedimento esse que, no plano da palavra, sempre foi característico do fazer literário. Uma das dúvidas daí resultantes diz respeito às decorrências que tal prática pode virtualmente trazer no que tange à imaginação narrativa. O “isto foi" pensado por Roland Barthes, o inabordável que transita entre o studium e o punctum, mais e mais movente nos incontáveis vídeos e fotos que a cada segundo são feitos e compartilhados, mantém sua potência de permanecer nos comovendo?

Nos três momentos desta edição, intimamente sintonizados através da vertente barthesiana e de uma fina escuta das suas vozes e tonalidades mais relevantes, a resposta à questão da chamada é inequivocamente afirmativa. De modo que, para o dossiê "Políticas de la mirada. Intersecciones entre literatura y fotografía", Mario Cámara e Alejandra Josiowicz reúnem sete textos de ensaístas de diferentes países para pensar algumas das inúmeras possibilidades de cruzamentos que iluminem "de modo inovador", como afirmam na introdução, os dois modos de imaginar e recortar, ver e fazer arte e mundo: "Pretendemos estabelecer uma rede semântica entre o fotográfico e o literário a partir de uma série de 'cenas', quer dizer, de modos de inscrição do evento estético em uma constelação cambiante de percepções, afetos e interpretações que constituem a comunidade sensível e intelectual que torna possível esses intercâmbios". Os trabalhos, que abordam desde Mário de Andrade e Julio Cortázar até Oscar Wilde e José Martí, vêm assinados por Gabriela Nouzeilles, Paula Bertúa, Raul Antelo, Camilo Hernández Castellanos, Javier Guerrero, além dos próprios organizadores.

Já "Vida e obra. Roland Barthes e a escrita do diário", da safra recente do ensaísta rosarino Alberto Giordano, que tem dedicado sua atenção ao "giro autobiográfico" nas artes e na literatura em seus últimos livros, aborda um dos problemas centrais da trajetória de Barthes, tão persistente quanto as questões do texto e da fotografia. Nos termos do próprio Giordano: "Do textualismo generalizado se desprenderia o último momento, o do giro autobiográfico em clave nietzscheana: a literatura devém o Outro, o interlocutor eminente e desconhecido dos exercícios éticos que o crítico executa quando ensaia a microfísica de sua estupidez". Em seguida, aponta para o que seria uma significativa e irresistível casualidade: "Tanto o primeiro quanto o último ensaio que Barthes publicou em vida tratam da escrita do Diário". Isto foi? Isto é?... 
$\mathrm{Na}$ terceira parte desta edição aparece, portanto, a outra septena de trabalhos com e a partir de Roland Barthes, com suas "políticas do olhar" imbuídas de um viés politizado sempre fundamental em toda sua obra, além de extremamente estimulantes para os trabalhos que encontram nela a sua fonte, como os aqui presentes. $\mathrm{O}$ textos possuem a virtude de procurar se distanciar dos discursos prototípicos e previsíveis da esfera acadêmica, vistos enquanto lugares de mera figuração e quantificação em portais digitais, com o fim de investi-los de um quantum de energia de linguagem pouco comum em nosso meio. É propriamente o caso do primeiro destes textos, "Ipsum é! Istud é! Sobre o desafio de refletir sobre a fotografia na atualidade", de Teresa Lenzi, em que, a partir dos livros O óbvio e o obtuso e A câmara clara, apresenta-se a tese proposta por Simon Watney de que "as estruturas institucionais socioculturais constituem obstáculos para o deslizamento do 'fotográfico' em direção à sua pluralidade e diversidade", incluindo menções a fotógrafos contemporâneos, nos quais também se joga intensamente com a dimensão política, caso dos coletivos sociais Luther Blisset e Sonia Brunzels que proporiam uma "guerrilha da comunicação" como recurso de resistência à homogeneização sociocultural. Trata-se de algo que de fato se verifica mundo afora via redes digitais, mais ou menos precárias, mais ou menos vitais em sua obstinada construção de universos virtuais, nas fronteiras geopolíticas da vida como ela é em que pobreza e riqueza se encontram e, no mesmo gesto, se destroem.

No segundo texto, "Fotografia: câmara clara ou caixa preta?", Rafael Alonso, a partir de uma reflexão sobre o referente e um possível "fora" da linguagem, trata de por em choque e em contato A câmara clara (1980) de Barthes e a Filosofia da caixa preta (1983) de Vilém Flusser, após passar em revista outros conhecidos ensaios dedicados à fotografia de Walter Benjamin, Siegfried Kracauer e Susan Sontag, além de O imaginário (1940) de Sartre. Já, em "O fragmento como potência imaginária”, Olívia de Melo Fonseca rememora que "os fragmentos barthesianos resistem e sobrevivem ao entendimento histórico-linear do sujeito", vistos ademais enquanto um work in progress em que se inscreve um contra-discurso autobiográfico e romanesco. $\mathrm{Na}$ sequência, "O punctum da imagem", de Ana Bartolo, resgata a leitura crítica de André Rouillé do "isto-foi" barthesiano, na qual o historiador da arte enfatiza a atração irresistível que vem provocando ao longo do tempo esta "narrativa sobre a recepção de uma imagem fotrográfica". Tomando como referência as observações de Rouillé, a autora persegue a noção de punctum enquanto "um operador de temporalidades na imagem". E, em "Agora se pode fotografar tudo", Franklin Alves Dassie realiza uma reflexão e uma postulação da necessidade da experiência fotográfica como forma de resistência a um consumo compulsivo 
de imagens na contemporaneidade, a partir também e sobretudo de A câmara clara.

Nos dois últimos textos desta série, ambos compostos por duplas de pesquisadores, ressurge a questão da possibilidade da poesia concreta nos dias de hoje, em "Da letra à imagem: uma incursão no jogo poético de Knorr”, de Lívia Ribeiro Bertges e Vinícius Carvalho Pereira, e propõe-se uma intervenção crítica em forma de homenagem ao Barthes narrador de $A$ câmara clara, em "O registro do indizível: um olhar sobre a arte fotográfica a partir dos pressupostos de Roland Barthes", de Sandra Klafke e Jorge Pedro Sousa. No primeiro vem à tona o OLHLO, experimento de poesia visual e livro-objeto de Luis Augusto Knop de Mendonça pensado enquanto manifestação de uma "estética híbrida" a partir de postulados de Barthes e de Derrida, entre a grafé e a imagem. E, no trabalho final, Klafke e Sousa assumem barthesianamente que "a imagem é um universo refrator de inúmeras semânticas e [...] o olhar do espectador só é capaz de alcançar, quando frente a ela, os traços imagéticos que reflitam a si mesmo".

Olhar, olhar-se, imaginar, imaginar-se: de fato, entre as duas séries dedicadas às políticas do olhar e os sete textos publicados em cada uma delas parece possível tomar o diário de escritor estudado por Alberto Giordano como uma espécie de ligadura ou costura através da qual crítica e ficção, punctum e studium, prazer e gozo, passado e presente se ofereçam à mirada do leitor, através das renovadas intervenções críticas tributárias do pensamento de Roland Barthes, a exemplo desta que acabamos de apresentar.

os editores 